\title{
Report of a patient with acne conglobata and perifolliculitis capitis abscedens et suffodiens
}

\author{
Mónica Lorena Cárdenas, MD¹, Francisco López, MD¹, Luis Hernando Moreno, MD² \\ SUMMARY
}

Perifoliculitis capitis abscedens et suffodiens, dissecting folliculitis, dissecting cellulitis, or Hoffman disease is a rare, inflammatory and chronic condition, which affects the scalp of young black men, mainly characterized by the appearance of nodules and abscesses that drain purulent material with fistulas and pathways, leading ultimately to scarring alopecia. At present, this condition is defined as a primary disorder of follicular keratinization, being part of the triad or tetrad of follicular occlusion. One third of the cases are associated with acne conglobata as a primary event. Management, frustrating for many years, is promising with the successful use of isotretinoin and a combination of medications that intervene each of its physiopathological principles.

Keywords: Perifolliculitis capitis abscedens et suffodiens; Acné conglobata; Dissecting cellulitis of scalp.

Colomb Med. 2011; 42: 224-7

Informe de un paciente con acné conglobata y perifolliculitis capitis abscedens et suffodiens

\section{RESUMEN}

Perifolliculitis capitis abscedens et suffodiens, foliculitis disecante, celulitis disecante o enfermedad de Hoffman, es una condición inflamatoria rara, crónica, que afecta el escalpo de hombres jóvenes sobre todo de raza negra, caracterizada por aparición de nódulos y abscesos que drenan material purulento con formación de fístulas y trayectos, conduciendo finalmente a alopecia cicatrizal. En la actualidad se entiende esta entidad como un trastorno primario de la queratinización folicular, haciendo parte de la tríada de oclusión folicular, consistente en la presencia de 3 ó 4 de las siguientes entidades: acné conglobata, perifoliculitis capitis abscedens et suffodiens, hidradenitis supurativa y quiste pilonidal. La tercera parte de los casos se asocia con acné conglobata como evento primario. Su manejo, frustrante durante muchos años, tiene nuevas esperanzas con el uso exitoso de isotretinoína y combinación de fármacos que intervienen cada uno de sus principios fisiopatológicos.

Palabras clave: Perifolliculitis capitis abscedens et suffodiens; Acne conglobata; Celulitis disecante del escalpo.

Colomb Med. 2011; 42: 224-7

\section{CASE REPORT}

Twenty-two-year old male patient, residing in the municipality of Yumbo, Colombia, who since he was 14 years of age presented the formation of suppurative inflammatory nodular lesions on the face and back, and since he was 20 years of age this was accompanied by a new appearance of nodules of similar characteristics on the scalp. Ever since then, he has received multiple antibiotic schemes with trimetoprim-sulfametoxasol among others, without improvement.

In September 2008, the condition worsened with the

1. Resident, Department of Dermatology and Dermatologic Surgery, Faculty of Health, Universidad del Valle, Cali, Colombia.e-mail: fjlm76@hotmail.com

2. Head, Department of Dermatology and Dermatologic Surgery, Faculty of Health, Universidad del Valle, Cali, Colombia. e-mail: luis.moreno@imbanaco.com.co Received for publication August 26, 2009 Accepted for publication December 1, 2009 


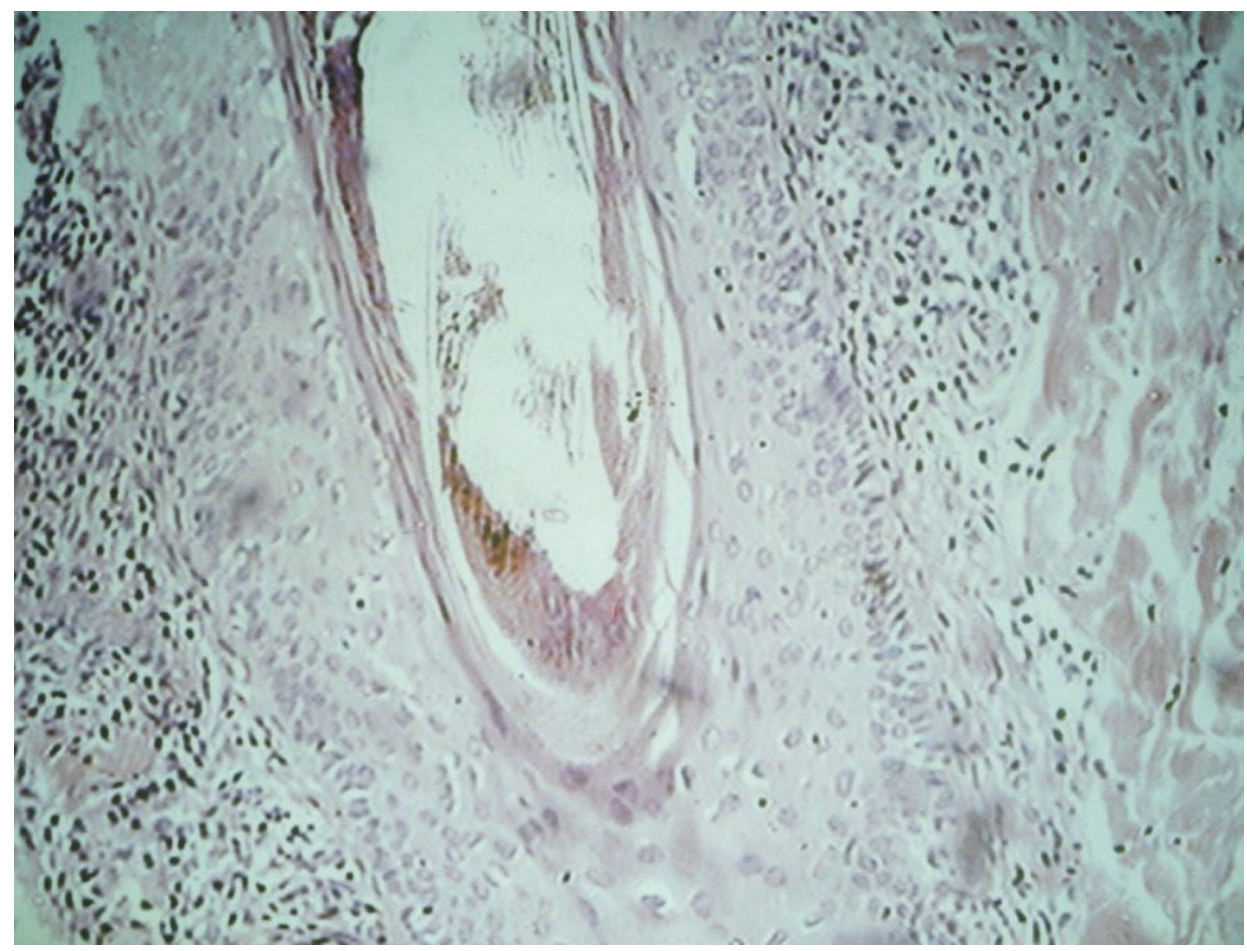

Figure 1. Mixed Inflammatory infiltrate with polymorphonuclear predominance compromising the hair follicle

increase of the number of lesions and constitutional compromise with fever and arthralgia, initially managed at a periphery hospital center with clindamycin and intravenous oxacillin without improvement, for which he was sent Hospital Universitario del Valle. There were no other personal antecedents; among the family members, the mother had suffered from acne.

Upon admission to our institution, we found a patient, phototype $\mathrm{V}$, with multiple painful, fluctuating nodular lesions, with abundant bad smelling spontaneous purulent secretion, formation of fistulous tracts that suppurated after digital pressure at a distance, compromising the whole face, neck, and scalp region. All the lesions were intercalated with uniform scarring areas on the face and sinuous on the scalp. The hemogram revealed leukocytosis with neutrophilia, C-reactive protein elevated 100 times the reference value, the rheumatoid factor, VDRL and HIV were negative. The histopathology of samples taken from the head and scalp reported occlusion folliculitis with mixed inflammatory infiltrate predominantly polymorphonuclear with destruction of the epidermal basal layer, stratum corneum spongiosis, exocytosis, and formation of intraepidermal abscesses; the inflammatory infiltrate compromised the follicular epithelium and the adjacent adnexal structures, findings compatible with acne conglobata and perifolliculitis capitis abscedens et suffodiens (Figure 1).

Upon admission, systemic treatment was begun with $300 \mathrm{mg}$ of rifampicin every 12 hours, $100 \mathrm{mg}$ per day of zinc gluconate, and $50 \mathrm{mg}$ per day of oral prednisolone with approximately $70 \%$ improvement of the inflammatory lesions and complete improvement of the suppuration. The patient suspended prednisolone and received rifampicin and zinc gluconate irregularly because of economic reasons and did not attend followup control visits for five months, reappearing for consultation in March of 2009. At that moment, the patient had scarce inflammatory lesions, light purulent secretion and vast scars in places previously compromised (Figures 2, 3, 4).

Extension studies to discard associated seronegative spondyloarthropathy consistent in cervical X-ray, lumbosacral spine X-ray, in frog position and Ferguson, did not reveal evidence of cervical abnormalities or sacroiliitis. 


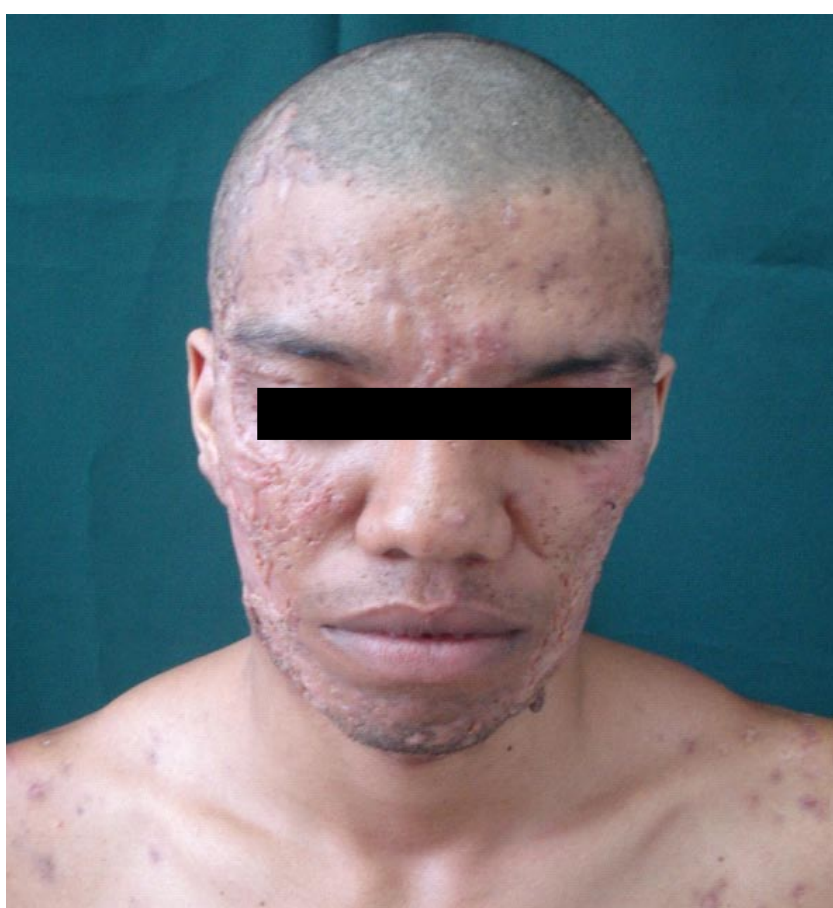

Figure 2. Multiple nodules, cysts, and cicatricial areas compromising the whole face

\section{DISCUSSION}

Perifolliculitis capitis abscedens et suffodiens is a rare, chronic, progressive, and inflammatory disease of the scalp, which almost exclusively affects Afrodescendant males $(80 \%)$ between 18 and 40 years of age. It was detected for the first time in 1903 by Splitzer in association with severe acne conglobata under the name of dermatitis follicularis et perifollicularis conglobata. In 1907, Hoffman described it as an isolated condition.

It is currently considered a primary disorder follicular occlusion, being part of the tetrad of follicular occlusion along with acne conglobata, hidradenitis suppurativa and pilonidal cysts. Bacterial infection is a secondary event and in most cases corresponds to Staphylococcus aureus $^{1}$.

Lesions begin as follicular pustules on the occipital region or scalp vertex then they become painful firm or fluctuating nodules, which could be interconnected through fistulous tracts, with discharge of purulent material. Initially, non-scarring alopecia is developed
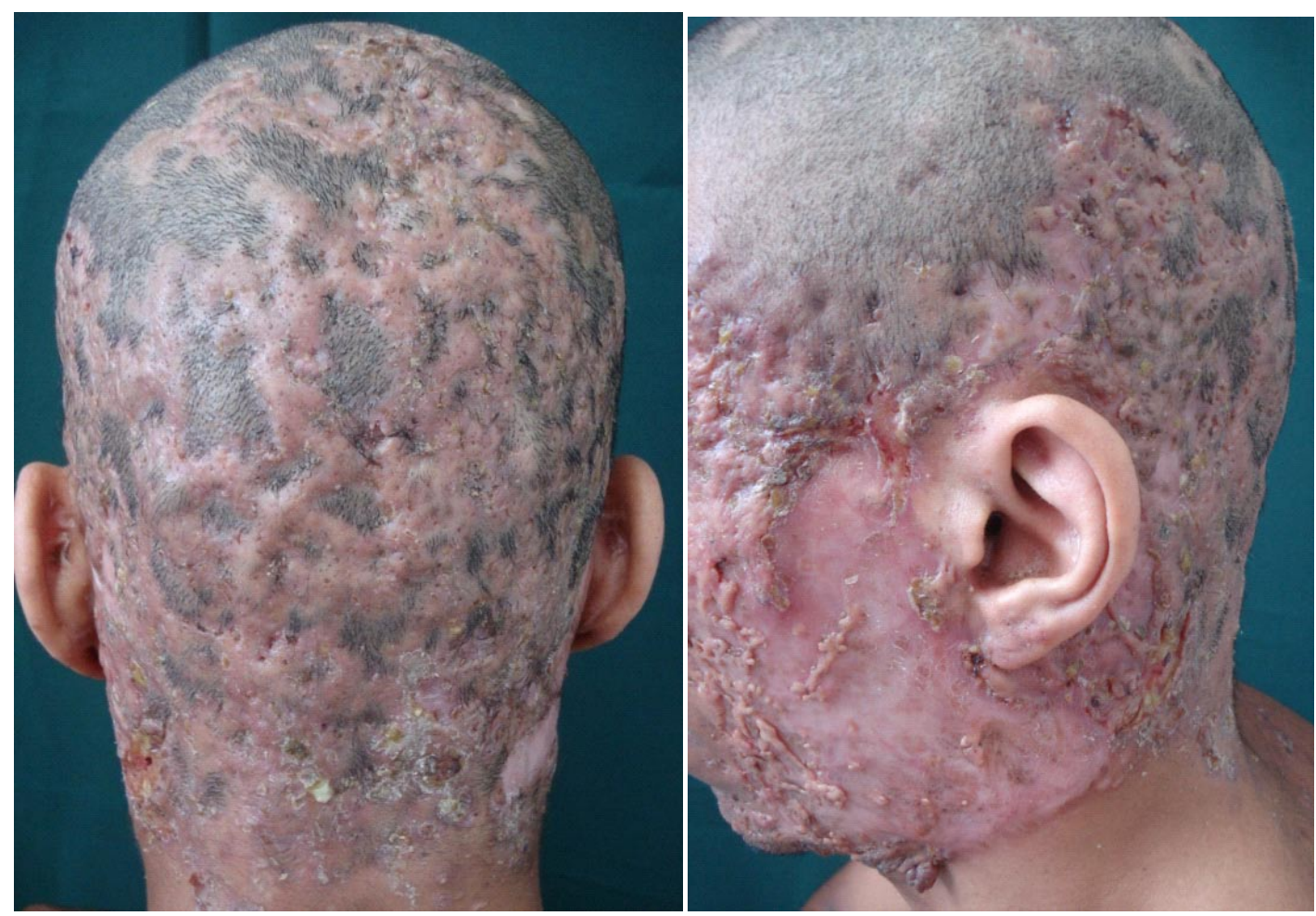

Figure 3. Fluctuating nodules and fistulous tracts with purulent secretion, scabs, and vast cicatricial areas 
on the nodules. The Pull test was positive. This test consists of taking approximately 60 strands of hair and pulling them from the proximal to the distal part, if six or more hairs are detached this indicates the test is positive and there is an active loss of hair. In the long term, if the disease is not treated, hypertrophic scars, keloids, and scarring alopecia are developed.

Coexistence with acne conglobata or hidradenitis suppurativa is present in $1 / 3$ of the cases, which implies a risk for developing seronegative spondyloarthropathies HLA-B27, with compromise of axial joints or asymmetric peripheral arthritis. Differential diagnosis includes other inflammatory disorders of the scalp like tinea capitis, or a variant of folliculotropic mycosis fungoides with follicular mucinosis, and folliculitis decalvans, among other primary scarring alopecia.

Treatment had been unsuccessful until a few years ago, when isotretinoin became a first-line pharmacological treatment with dosages of $0.5-1 \mathrm{mg} / \mathrm{kg} /$ day alone or combined with antibiotics like trimetropin sulfa, rifampicin, with good results, although with recurrence. Isotretinoin is part of the group of vitamin A polycyclic synthetic analogs that regulate keratinization of the epidermis and hair follicles; additionally, it is believed to inhibit the activation and proliferation of $\mathrm{T}$ lymphocytes.

Historically, multiple treatments have been described with immunosuppressant drugs like systemic corticosteroids or intralesional, topical and systemic antibiotic, immunomodulators like zinc sulfate and drainage of suppurative lesions ${ }^{2}$.

Bolz et $a l^{3}{ }^{3}$, reported a clinical case with good response and lack of recurrence with combined therapy of $80 \mathrm{mg}$ of isotretinoin plus $100 \mathrm{mg}$ of dapsone daily and then maintenance therapy with $50 \mathrm{mg}$ of dapsone interdaily.

Recently, successful treatment of this condition has been described with tumor necrosis factoralpha (TNFá) inhibitors like infliximab ${ }^{4}$ and adalimumab ${ }^{5}$.

Ours is a case of interest, with association of two components of the follicular occlusion tetrad (peri-

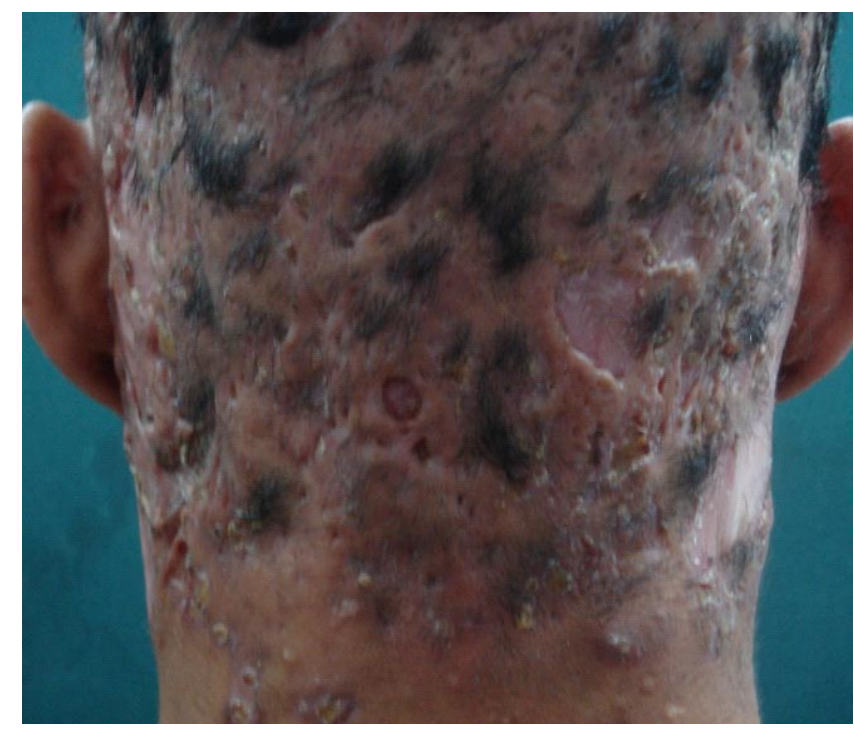

Figure 3. Fistulous tracts, scabs, and a vast area of alopecia

folliculitis capitis abscedens et suffodiens and acne conglobata), with a $70 \%$ response, in spite of the discontinuity of the treatment with combined therapy of zinc gluconate, prednisolone and rifampicin, where each intervenes directly upon the relevant physiopathological factors in each of these conditions.

Conflict of interest. None of the authors has conflicts of interest related to this study.

\section{REFERENCES}

1. Ross E, Tan E. Shapiro update on primary cicatricial alopecias. J Am Acad Dermatol. 2005; 53: 1-37.

2. Price V. The medical treatment of cicatricial alopecia. Semin Cutan Med Surg. 2006; 25: 56-9.

3. Bolz S, Jappe U, Hartschuh W. Successful treatment of perifolliculitis capitis abscedens et suffodiens with combined isotretinoin and dapsone. J Dtsch Dermatol Ges. 2008; 6: 44-7.

4. BrandtH, Malheiros A, Teixeira M, Machado M. Perifolliculitis capitis abscedens et suffodiens successfully controlled with infliximab. Br J Dermatol. 2008; 159: 506-7.

5. Sukhatme S, Gottlieb A. Dissecting cellulitis of the scalp treated with adalimumab. J Am Acad Dermatol. 2009; 60: AB52. 